\title{
THE INFLUENCE OF CORROSION OF ZINC POWDER ON MECHANICAL PROPERTIES OF CONCRETE
}

\author{
\#PETR POKORNÝ, DANIEL DOBIÁŠ, DAVID ČÍTEK \\ Czech Technical University in Prague, Klokner Institute, Šolinova 7, 16608 Prague, Czech Republic \\ "E-mail: Petr.Pokorny@cvut.cz
}

Submitted January 8, 2016; accepted April 11, 2016

\begin{abstract}
Keywords: Corrosion of steel in concrete, Hot-dip galvanized reinforcement, Zinc, Heat of hydration, Compression strength, Modulus of elasticity

This paper studies the effect of zinc corrosion in fresh concrete on the process of its hydration and evolution of common mechanical properties. Process of hydration was monitored by temperature measurement of hydrating concrete contaminated with zinc powder $(0.5 ; 5.0 \mathrm{wt} . \%)$ in closed system. Mechanical properties were monitored in similarly contaminated concrete samples (compressive cubic strength, compression modulus of elasticity). The results suggest that zinc corrosion products retard the concrete hydration and evolution of mechanical properties, however, forming hydrogen also has some negative effect.
\end{abstract}

\section{INTRODUCTION}

Utilization of hot-dip galvanized zinc coating as a means of anti-corrosion protection of carbon steel concrete reinforcement can be one of many measures to enhance the lifetime of concrete steel construction. Application of this surface treatment enhances the resistance of construction against carbonation, however its resistance of the coating against chloride anions is in question, and even more so is the effect of zinc coating on bond-strength between concrete and the reinforcement $[1,2,3]$.

After the hot-dip galvanized steel is set into concrete, the initial corrosion reaction - anodic dissolution of zinc takes place, producing $\mathrm{Zn}^{2+}$ (Equation 1):

$$
\mathrm{Zn}-2 \mathrm{e}^{-} \rightarrow \mathrm{Zn}^{2+}
$$

In strongly alkaline environment, the zinc cation transforms to zinc hydroxide (Equation 2):

$$
\mathrm{Zn}^{2+}+2 \mathrm{OH}^{-} \rightarrow \mathrm{Zn}(\mathrm{OH})_{2}
$$

Zinc hydroxide ( $\varepsilon-$ modification) together with $\mathrm{ZnO}$ constitute the minor part of corrosion products on zinc or hot-dip galvanized steel $[4,5,6]$. Major component in alkaline environment in presence of $\mathrm{Ca}(\mathrm{OH})_{2}$ is $\mathrm{Ca}\left[\mathrm{Zn}(\mathrm{OH})_{3}\right]_{2} \cdot 2 \mathrm{H}_{2} \mathrm{O}$. This dihydrate of calcium zincate (more precisely calcium bis(trihydroxydizincate) dihydrate) forms preferentially if the $\mathrm{pH}$ of model pore solution is above 12.6 (some sources state the threshold to be 12.8) [7-10]. Reaction of formation of this compound can be described as follows (Equations 3-5) [1, 4, 7, 8].

$$
\begin{aligned}
& \mathrm{Zn}(\mathrm{OH})_{2}+\mathrm{Ca}(\mathrm{OH})_{2}+2 \mathrm{H}_{2} \mathrm{O} \rightarrow \\
& \rightarrow \mathrm{Ca}\left[\mathrm{Zn}(\mathrm{OH})_{3}\right]_{2} \cdot 2 \mathrm{H}_{2} \mathrm{O} \\
& 2\left[\mathrm{Zn}(\mathrm{OH})_{4}\right]^{2-}+\mathrm{Ca}^{2+}+2 \mathrm{H}_{2} \mathrm{O} \rightarrow \\
& \rightarrow \mathrm{Ca}\left[\mathrm{Zn}(\mathrm{OH})_{3}\right]_{2} \cdot 2 \mathrm{H}_{2} \mathrm{O}+2 \mathrm{OH}^{-} \\
& 2 \mathrm{Zn}+\mathrm{Ca}(\mathrm{OH})_{2}+6 \mathrm{H}_{2} \mathrm{O} \rightarrow \\
& \rightarrow \mathrm{Ca}\left[\mathrm{Zn}(\mathrm{OH})_{3}\right]_{2} \cdot 2 \mathrm{H}_{2} \mathrm{O}+2 \mathrm{H}_{2}
\end{aligned}
$$

Transition of hot-dip galvanized steel from active to passive steel is typically explained by formation of crystalline $\mathrm{Ca}\left[\mathrm{Zn}(\mathrm{OH})_{3}\right]_{2} \cdot 2 \mathrm{H}_{2} \mathrm{O}$. It has been stated by several authors that up to $\mathrm{pH} 13.3$ of the model pore solution, the surface becomes passive by the formation of the zincate [11-14]. However, there are also works with data contradicting this conclusion, explaining the transition to passive state is caused by $\mathrm{ZnO}$ and $\varepsilon-\mathrm{Zn}(\mathrm{OH})_{2}[15,16,17]$.

It has not yet been explained in detail whether this phase on the surface of hot-dip galvanized steel has positive or negative effect on its bond strength with concrete $[1,2]$. According to the free corrosion potential $\left(E_{\text {corr }}\right)$ data, the product of cathodic corrosion process is hydrogen (6); the potential is within the range of hydrogen stability in potential-pH diagram [18]

$$
2 \mathrm{H}_{2} \mathrm{O}+2 \mathrm{e}^{-} \rightarrow 2 \mathrm{OH}^{-}+\mathrm{H}_{2}
$$

Effect of spontaneous hydrogen evolution on the surface of hot-dip galvanized steel or pure zinc has unambiguously negative effect on porosity of cement on phase interface [2]. Filing of these pores by zinc corrosion products is nowadays questioned [19-23]. 
It has been mentioned before that zinc and $\mathrm{ZnO}$ can slow down cement curing by formation of $\mathrm{Zn}(\mathrm{OH})_{2}$ and/or $\left[\mathrm{Zn}(\mathrm{OH})_{4}\right]^{2-}$. This phenomenon is commonly explained by encasing the unreacted grains of cement by these compounds, thus slowing down the hydration [2427]. However, it has been also shown that zinc corrosion products are partially able to integrate with forming $\mathrm{C}-\mathrm{S}-\mathrm{H}$ gel and change its morphology to fibrous. It is also claimed that this phenomenon can, after 28 days, lead to enhancement of mechanical properties of contaminated concrete $[28,29,30]$.

This paper is focused on effect of addition of high-purity zinc on evolution of mechanical properties (compressive cubic strength, static modulus of elasticity in compression) prepared solely from pure Portland cement. The effect of pure zinc addition on hydration heat was also studied.

Acquired data are discussed in broad context to evaluate the feasibility of hot-dip galvanized concrete reinforcement.

\section{EXPERIMENTAL}

Pure Portland cement CEM I was used to evaluate the effect of corrosion of zinc powder (analytical purity SIGMA - ALDRICH) on evolution of mechanical properties during cement curing. Cement composition is specified in Table 1; the content of specific oxides was measured by XRF. Since the corrosion behavior of zinc in fresh concrete can be affected by chloride anions $\left(\mathrm{Cl}^{-}\right)$and chromate anions $\left(\mathrm{CrO}_{4}^{2-}\right)$, the composition was further verified by ICP - OS method. Table 2 .

Composition of concrete mixture is summed up in

Prepared concrete mixtures were classified as $\mathrm{C} 30 / 37$ strength category and water coefficient $(\mathrm{w} / \mathrm{c})$ was 0.57 .

Table 1. Chemical analysis of the cement (XRF/ICP-OS), wt. \%.

\begin{tabular}{ccccc}
\hline $\mathrm{CaO}$ & $\mathrm{SiO}_{2}$ & $\mathrm{Al}_{2} \mathrm{O}_{3}$ & $\mathrm{Fe}_{2} \mathrm{O}_{3}$ & $\mathrm{SO}_{3}$ \\
\hline 56.1 & 27.3 & 4.9 & 3.4 & 2.4 \\
\hline \hline $\mathrm{MgO}$ & $\mathrm{Na}_{2} \mathrm{O}$ & $\mathrm{K}_{2} \mathrm{O}$ & $\mathrm{Cl}^{-}$ & $\mathrm{CrO}_{4}{ }^{2-}$ \\
\hline 3.5 & 0.2 & 0.5 & 0.048 & $1 \times 10^{-3}$ \\
\hline
\end{tabular}

Table 2. Composition of concrete mixture samples $\left(\mathrm{kg} \cdot \mathrm{m}^{-3}\right)$

\begin{tabular}{lc}
\hline Concrete composition & Amount $(\mathrm{kg})$ \\
\hline Cement (CEM I - 42,5 R) & 350 \\
Aggregate -1 (0/4 Dobř́n $)$ & 900 \\
Aggregate -2 (4/8 Dobřín $)$ & 585 \\
Aggregate -3 (8/16 Dobřín) & 285 \\
Water & 200 \\
\hline
\end{tabular}

Hydration process and evolution of mechanical properties (compressive cubic strength; static modulus of elasticity in compression) of pure concrete was compared with samples contaminated with zinc powder ( 0.5 wt. $\% \mathrm{Zn}$ and 5.0 wt. \% $\mathrm{Zn}$ (relative to dry cement mass)).

The hydration process was monitored by modified test - instead of conventional hydration heat, temperature was measured. Test composed of a thermocouple enclosed in the middle of cubic mould $\left(a_{c}=300 \mathrm{~mm}\right)$, fixed inside larger cube. The space between the two was insulated $\left(a_{i}=100 \mathrm{~mm}\right)$ by polystyrene layer (isolated system). Temperature of the inner system, composed of curing and eventually hardening concrete, was measured in 5 minute for 15 days. In total, 3 samples were measured - a cube without any added zinc, and two contaminated with zinc. Average air temperature in the room where the cubes were stored was $t_{r}=17.5 \pm 1.5^{\circ} \mathrm{C}$.

Additionally, mechanical properties of concrete contaminated with zinc were realized. First, the compressive cubic strength of samples was tested. Four parallel specimen were produced for each cube $\left(a_{c i}=150 \mathrm{~mm}\right)$, firstly non-contaminated and later contaminated with 0.5 wt. \% Zn and eventually 5.0 wt. \% Zn. Compressive cubic strength was measured on INSTRON $3000 \mathrm{kN}$ device.

After comparison measurement of compressive cubic strength, the static modulus of elasticity in compression was evaluated. Four samples (bars: $100 \times 100$ $\times 400 \mathrm{~mm}$ ) were used in each test. The properties were measured along the longitudinal axis. The loading was cyclic in range of $0.5 \mathrm{MPa}$ to $1 / 3$ of measured compressive cubic strength. Relative strain of concrete was measured during loading. Experimental device was the same as in the previous experiment. Compressive modulus of elasticity was calculated from the loading curve (stress - strain diagram).

\section{RESULTS AND DISCUSSION}

Recorded temperatures during hydration of concrete is summed up in Figure 1. It is apparent that addition of $0.5 \mathrm{wt}$ \% does not yet have effect on hydration. Slight elevation of temperature in the case of less-contaminated concrete sample relative to sample without zinc addition is caused only by zinc dissolution and formation of corrosion products (see the Introduction), because zinc dissolution in alkaline environment is an exothermic reaction.

On the opposite, higher addition of zinc powder $(5.0 \mathrm{wt} . \%)$ to the mixture clearly retards hydration process.

Relatively mild increase of temperature of concrete sample with high zinc addition is probably caused only by corrosion of zinc powder which is accompanied by hydrogen evolution in the whole sample. It needs to be 
emphasized that hydration is evidently not hindered just by corrosion products of zinc in alkaline environment in presence of calcium cations but also by the gaseous hydrogen. Forming gas displaces cement grains so far apart that they are not able to interact. Concrete samples contaminated with $5.0 \mathrm{wt}$. \% zinc are much larger in volume compared to non-contaminated samples. This is apparent from Figure 2 and Figure 3. Moreover, these samples have high degree of very atypical porosity (see Figure 4).

Imperfect hydration of zinc contaminated concrete facilitates evident deterioration of mechanical properties of concrete.

Figure 5 shows compressive cubic strength data (the average of 4 measurements) after 28 days of concrete curing. It is apparent from the figure that addition of 0.5 wt. $\% \mathrm{Zn}$ slightly reduces cubic strength. Addition of $5.0 \mathrm{wt} . \%$ of zinc reduces the compressive strength by up to a factor of 10 . Similarly, the elastic modulus of concrete with 5.0 wt. \% zinc addition is reduced about $25 \%$. Addition of 0.5 wt. $\%$ had no effect on value of elastic modulus (see Figure 6).

This work reasserts previous results suggesting that corrosion products of zinc in the fresh concrete have negative effect on hydration and thus also on mechanical properties evolution of mature concrete. Contamination of concrete with even small amounts of zinc does not significantly change the process of hydration and mechanical properties. The speculation can be thus drawn that reduced bond strength between concrete and hot-dip galvanized reinforcement is caused primarily by hydrogen evolution which clearly increases porosity of cement on phase interface of hot-dip galvanized reinforcement/concrete. It is also necessary to highlight that the concrete-reinforcement bond strength can be negatively affected by not only the hydrogen evolution but also formation of voluminous corrosion products from $\mathrm{Ca}\left[\mathrm{Zn}(\mathrm{OH})_{3}\right]_{2} \cdot 2 \mathrm{H}_{2} \mathrm{O}$ or $\mathrm{Zn}_{5}(\mathrm{OH})_{6}\left(\mathrm{CO}_{3}\right)_{2}$ (in uncontaminated concrete) or, e.g. $\mathrm{Zn}_{5}(\mathrm{OH})_{8} \mathrm{Cl}_{2} \cdot \mathrm{H}_{2} \mathrm{O}$ (concrete contaminated by chlorides).

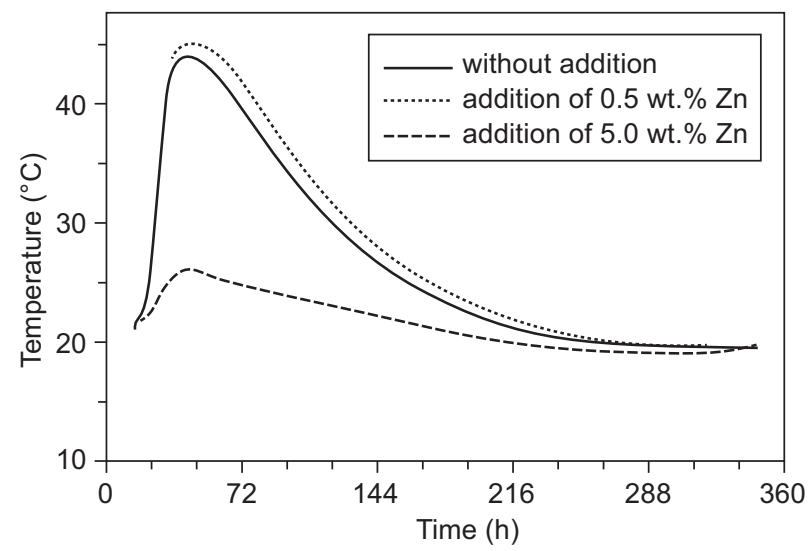

Figure 1. Hydration temperatures of hydrating concrete samples without addition or with a addition of zinc powder.

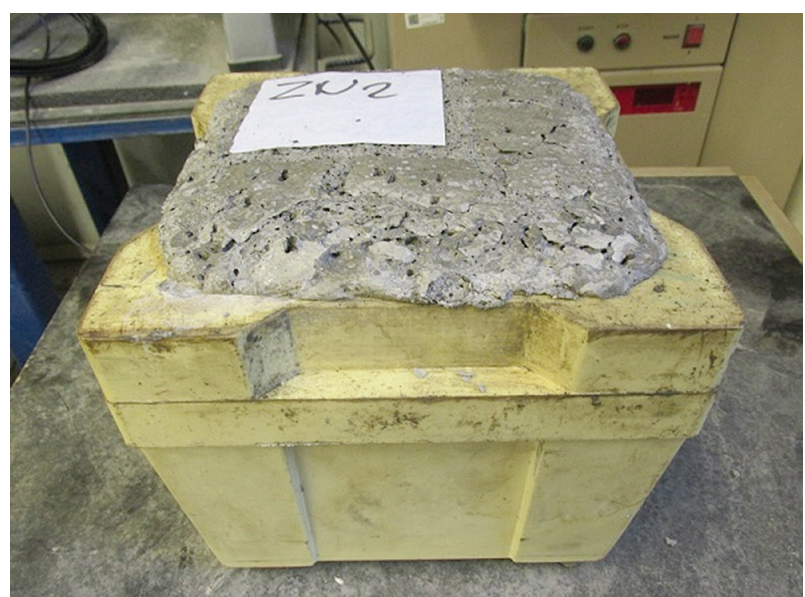

Figure 2. Appearance of "gass-filled" concrete sample with addition of $5.0 \mathrm{wt}$. \% $\mathrm{Zn}$.

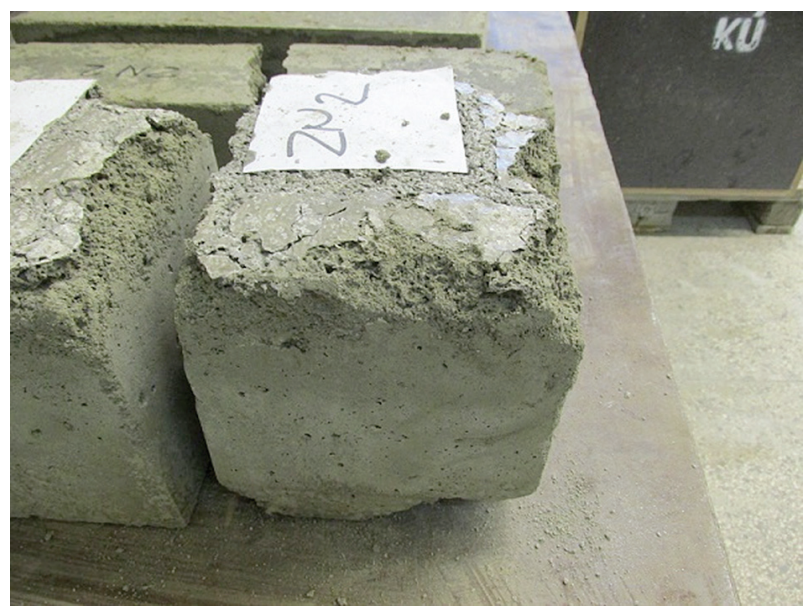

Figure 3. Another image of "gass-filled" concrete cubic sample with addition of $5.0 \mathrm{wt} . \% \mathrm{Zn}$.

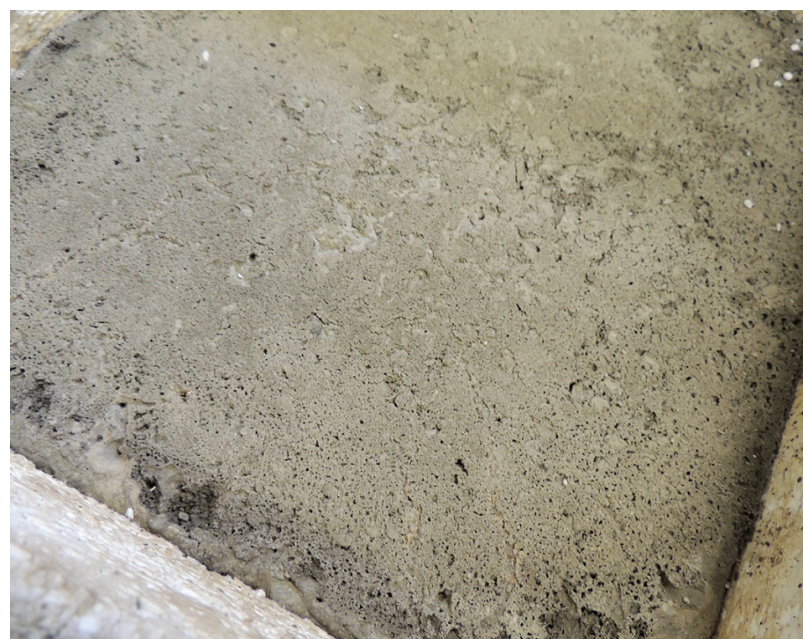

Figure 4. Detail depicting dramatic increase of porosity in sample of concrete with 5.0 wt. \% addition $\mathrm{Zn}$. 


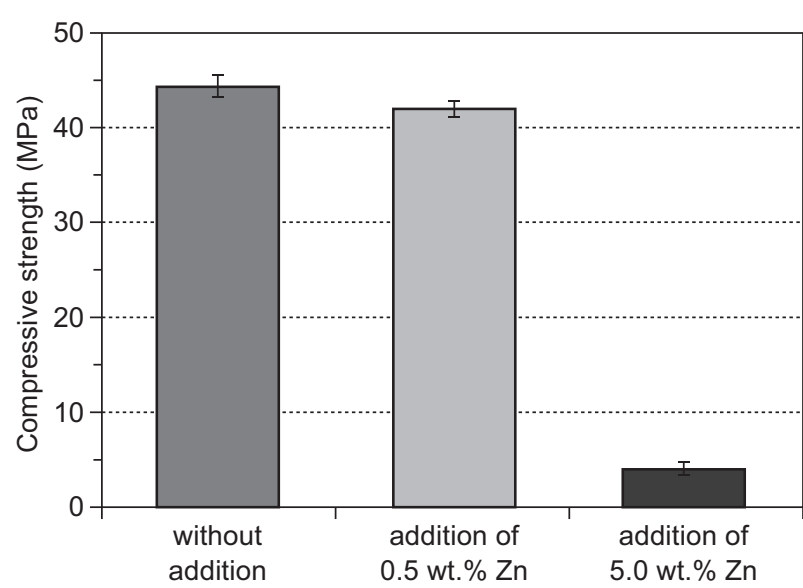

Figure 5. Comparison of compressive cubic strength of samples with different levels of zinc powder content.

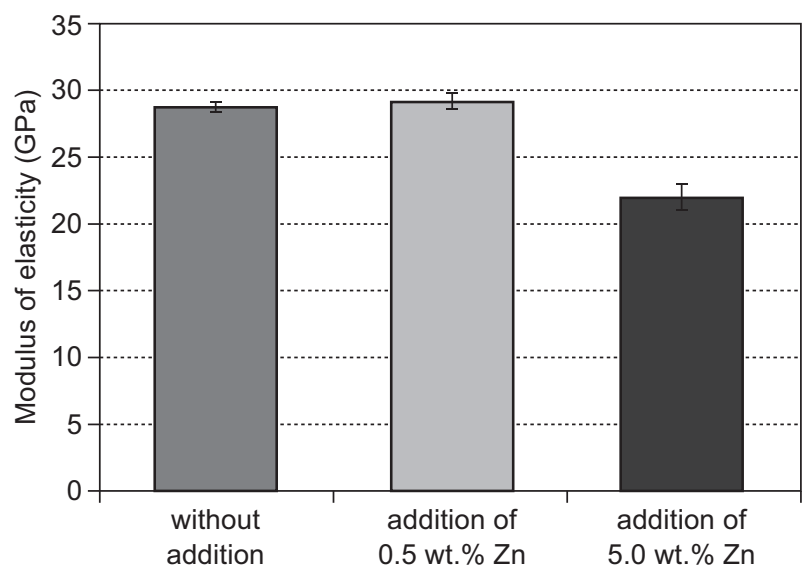

Figure 6. Comparison of compressive coefficient of elasticity of samples with different levels of zinc content.

\section{CONCLUSIONS}

This work clearly shows that corrosion of zinc retard the process of hydration of common concrete and thus also the evolution of their mechanical properties. It is important to mention that the hydration process and mechanical properties evolution are also affected by gaseous hydrogen. Its formation causes displacement of concrete grains thus preventing their interaction.

Lower amount of zinc in concrete $(0.5$ wt. $\%$ in this case) has no significant effect on hydration and hence no effect on mechanical properties evolution. It can be assumed that the main factor is the increased porosity caused by forming hydrogen which facilitates the reduced bond strength between hot-dip galvanized reinforcement and concrete.

Retardation of mechanical properties of cement on hot-dip galvanized reinforcement/cement (ITZ) by zinc corrosion products has probably only minor effect on their bond strength.
Acknowledgement

This work was accomplished with the financial support from the Grant Agency of the Czech Republic, reg. number 14-20856S.

\section{REFERENCES}

1. Yeomans S. R. (2004).Galvanized steel reinforcement in concrete. $2^{\text {nd }}$ ed. Elsevier.

2. Pokorný P., Dobiáš D., Vokáč M., Kouřil M., Kubásek J. (2015). The assessment of the impact of corrosion of galvanized steel on bond strength of plain bars with "NSC" concrete. Koroze a ochrana materiálu, 59 (2), 53 - 65. doi:10.1515/kom-2015-0014

3. Pokorný P., Kouřil M., Stoulil J., Bouška P., Simon P., Juránek P. (2015): Problems and normative evaluation of bond-strength tests for reinforcement and concrete. Materials and Technology, 49 (6), 57 - 66. doi:10.17222/ mit.2014.227

4. Macias A., Andrade C. (1987): Corrosion of galvanized steel in diluate $\mathrm{Ca}(\mathrm{OH})_{2}$ solutions (pH 11,1-12,6). British Corrosion Journal, 22 (3), 162-171. doi:10.1179/ 000705987798271505

5. Liu M. B., Faulds B. R., Cook G. M., Yao N. P. (1981): Conductivity of $\mathrm{KOH}$ electrolyte supersaturated with zincate. Electrochemical Science and Technology, 128 (3), 2049-2052. doi:10.1149/1.2127187

6. Keily T., Sinclair T. J. (1981): Effect of additives on the corrosion of zinc in $\mathrm{KOH}$ solution. Journal of Power Sources, 6, 47-62. doi:10.1016/0378-7753(81)80005-5

7. Bowsher B. (2009). Corrosion protection of reinforcing steel-Technical report fib. FIB Press.

8. Andrade C., Holst J. D., Nürnberger U., Whiteley J. D., Woodman N. (1992). Protection System for reinforcement, $C E B$ - Bulletin D'Information. Ceb-Office- Press.

9. Yeomans S. R. (1995). Galvanized steel reinforcement A prespect view, in: Swamy R. N. Real World Concrete Symposium. ACI International office Press. pp. 57-70.

10. Yeomans S. R. (2002): Galvanized reinforcing steel. Corrosion Management, 1, 3-6.

11. Blanco M. T., Macias A., Andrade C. (1984): SEM study of the corrosion products of galvanized reinforcements immersed in solution in the $\mathrm{pH}$ range 12,6-13,6. British Corrosion Journal, 19 (1), 41-48. doi:10.1179/00070598479827 3524

12. Macias A., Andrade C. (1987): Corrosion of galvanized steel reinforcements in alkaline solutions, (Part 1: Electrochemical results). British Corrosion Journal, 22 (3), 113118. doi:10.1179/000705987798271631

13. Macias A., Andrade C. (1987): Corrosion of galvanized steel reinforcements in alkaline solutions, (Part 2: SEM study and identification of corrosion products). British Corrosion Journal, 22 (3), 119-130. doi:10.1179/ 000705987798271749

14. Macias A., Andrade C. (1986): Stability of the calcium hydroxyzincate protective layer developer on galvanized reinforcements after a further increase of the $\mathrm{pH}$ value, Materiales des Construcción, 36, 19-28. doi:10.3989/ mc.1986.v36.i204.882 
15. Wienerová K., Stoulil J., Kouřil M. (2010): Koroze a ochrana zinkované oceli v prostředí betonu, Koroze a ochrana materiálu, 54 (4), 148 - 154.

16. Menzel K. (1992). Zur Korrosion von verzinktem Stahl in Kontakt mit Beton - IWB. Universität Stuttgart Press.

17. Schwick W., Diehl R., Carpentier C.-D. (1965): Corrosion of zinc in concrete, Nature, 229, 184.

18. Fratesi R., Moriconi G., Coppola L. (1996). The influence of steel galvanization on rebars behaviour in concrete, in: Corrosion of Reinforcement in Concrete Construction. The Royal Society of Chemistry Press. pp. 630-640.

19. Belaid F., Arliguie G., Francois R. (2001): Porous structure of the ITZ around galvanized and ordinary steel reinforcement. Cement and Concrete Research, 31 (11),15611566. doi:10.1016/S0008-8846(01)00597-X

20. Rovnaníková P., Bayer P. (2003). Study of the interfacial transition zone between cement paste and zinc coated steel reinforcement. in: Corrosion of Underground Structures. pp. $65-70$.

21. Rovaníková P., Bayer P. (2004). Role of the physical chemical methods for evaluation of the relation between galvanized steel-cement stone. in: CERM pp. 469-474.

22. Rovnaníková P., Bayer P. (2003). Microstructure of hardened portland cement paste in galvanized reinforcement surroundings, in: 9 - Konference žárového zinkování. pp. $57-62$.
23. Rovnaníková P., Bayer P. (2004). Vlastnosti cementového tmelu v betonu na styku s pozinkovanou výztuží, in: 11 -Betonářské dny. pp. 542-547.

24. Arliguie G., Ollivier J. P., Grandet J. (1982): Etude de l'effect retardateur du zinc sur l'hydratation de la pate de ciment Portland. Cement and Concrete Research, 12, $79-$ 86. doi:10.1016/0008-8846(82)90101-6

25. Asavapisit S., Fowler G. (1997): Solution chemistry during cement hydratation in the presence of metal hydroxide wastes. Cement and Concrete Research, 27 (8), 1249 -1260. doi:10.1016/S0008-8846(97)00109-9

26. Mellado A., Borrachero M. V., Soriano L., Paya J., Monzo J. (2013): Immobilization of $\mathrm{Zn}(\mathrm{II})$ in portland cement pastes. Journal of Thermal Analysis and Calorimetry, 112, 1377-1389. doi:10.1007/s10973-012-2705-8

27. Tashiro C., Oba J. (1979): The effect of $\mathrm{Cr}_{2} \mathrm{O}_{3}, \mathrm{Cu}(\mathrm{OH})_{2}$, $\mathrm{ZnO}$ and $\mathrm{PbO}$ on the compressive strength and the hydrates of the hardened $\mathrm{C}_{3} \mathrm{~A}$ paste. Cement and Concrete Research, 9 (2), 253-258. doi:10.1016/0008-8846(79)90032-2

28. Lieber W. (1969). The influence of lead and zinc compounds on the hydratation of Portland cement, in: International Symposium on the Chemistry of Cements. pp. 444-454.

29. Lieber W., Gebauer J. (1969): Einbau von Zink in Calciumsilicathydrate. Zement-Klak-Gips, 4, 161-164.

30. KochR.,WohlfahrtR.(1988): EinflußvonBetonzusatzstoffen und - mitteln auf das Verbundenverhalten feuerverzinkter Betonstähle, Betonwerk + Fertigteil- Technik, 3, 64-70. 